\title{
The Use of Social Media in Research on Gambling: a Systematic Review
}

\author{
Richard J. E. James ${ }^{1}$ (D) Alex Bradley ${ }^{2}$ (D) \\ Accepted: 19 March 2021 / Published online: 11 May 2021 \\ (C) The Author(s) 2021
}

\begin{abstract}
Purpose of Review Social media enables a range of possibilities in the way gamblers and gambling operators interact and content communicate with gambling. The purpose of this systematic review was to synthesise the extant literature to identify the ways in which social media has been investigated in the context of gambling.

Recent Findings A systematic review of the literature identified 41 papers that collected primary data pertinent to gambling and social media from multiple disciplines. These papers broadly fell into three themes: communication, community and calculation (of sentiment). Papers on communication focused on the content of gambling advertising on social media and the impact on people exposed to it. Studies of gambling communities studied the activity and structures of discussion groups on social media concerning recreational or problematic gambling. Papers on calculation collated social media data to assess sentiment and compared it against betting odds.

Summary There is an emerging multidisciplinary literature that has looked at the use of social media in relation to gambling. There is preliminary evidence that the content and the reach of gambling advertising on social media is a source of concern, particularly for younger people. The themes discussed on gambling support forums appear to be common across communities, focusing on negative emotions, recovery, addictive products and financial support. Using social media to assess sentiment appears to be particularly effective at identifying potential upsets in sporting matches. Future suggestions for research are explored.
\end{abstract}

Keywords Online gambling $\cdot$ Online betting $\cdot$ Social media $\cdot$ Twitter $\cdot$ Sports betting

\section{Introduction}

The internet has changed the way in which we communicate with each other and entertain ourselves. The gambling sector was an early adopter of online innovation [1]. One of the major developments has been the proliferation of social media, the communities and networks that enable the sharing of content between groups of people. The aim of this paper is to review the different research questions, methods and findings

This article is part of the Topical Collection on Gambling

Richard J. E. James

Richard.James4@nottingham.ac.uk

1 School of Psychology, University of Nottingham, Nottingham NG7 2RD, UK

2 School of Education and Sociology, University of Portsmouth, Portsmouth, UK of studies that have looked at the intersection between social media and gambling research.

\section{Social Media and Gambling}

Kaplan and Haenlein [2] define social media by the use of Web 2.0 functionalities (e.g. Adobe Flash, RSS, AJAX), and the enabling and delivery of user-generated contentmultimedia such as text, images, videos and sound. This encompasses a range of communities from blogs to online games and to social networking websites. In addition there are discussion forums that do not use Web 2.0 capabilities but involve the sharing of user content that are part of the same continuity as social media. Social media has itself evolved considerably over the last decade since, as most people now use social media in their daily lives, accessed through a diverse array of devices [3]. The most prominent accounts on social media now reach millions of people [4], and it has been 
adopted by businesses, pressure groups and political figures alike to reach the public [5].

Gambling companies have embraced social media as a means of communicating with potential customers. In the UK, analysis of the public accounts of gambling companies indicated that in 2017, around $60 \%$ of gambling advertising expenditure was spent on online advertising [6]. Social media represents around $10 \%$ of total advertising spend, and spend trebled between 2014 and 2017 [6]. Building on the existing literature in gambling advertising, there have been a number of studies that have looked at the content of gambling advertisements on social media $[7 \bullet \bullet, 8 \bullet \bullet, 9 \bullet \bullet]$.

The proliferation of social media has allowed communities of likeminded people to propagate. In the case of gambling, groups of people discussing topics and issues related to both recreational and problematic gambling activities have developed. This has led to an interest in the nature of the content discussed, and the dynamics of these communities $[10 \bullet \cdot$. Because many people who experience difficulties relating to gambling disorder do not undergo formal treatment [11], discussion groups represent an important source of informal care and a source of information for an even larger potential population who lurk and do not participate in the forums [12].

One area in which the role of social media in gambling has been extensively explored and is not considered in the scope of this review is in the context of social casino games. We recommend readers interested in this topic to reviews by Sirola et al. [13], and Gainsbury et al. [14-16]. Social casino games are simulated gambling games, or games with gambling themes, that are free to play on social media platforms, particularly Facebook. There is a developed literature on the role social games have on the transition to real money gambling and potentially addictive behaviour. However, social gaming is becoming less and less integrated with social media: the vast majority of social games are now available as standalone mobile applications as well as via social media. As web browsers increasingly discontinue plugins (e.g. Flash) that are used by these games, players are increasingly likely to access them outside of social media. Further, although of interest to gambling researchers for many reasons, these are not classified as gambling per se. Gambling regulators have typically not treated them as a gambling activity because they do not involve the wagering of real money. Although many offer microtransactions, there is no way to cash out virtual 'winnings' and so do not meet legal definitions of gambling in many, but by no means all, countries.

The purpose of this systematic review was to build a comprehensive overview of the current literature relating to social media and gambling. In doing so, we aim to categorise the types of study in the field and highlight existing knowledge gaps and areas where further investigation is likely to be fruitful.

\section{Method}

\section{Search Strategy}

Relevant studies were identified through searching electronic databases and citation searches. Four electronic databases were searched: Google Scholar, Web of Science, Scopus, and EBSCO Psychology and Behavioural Collection. A range of search terms were used to capture different social media platforms (Social Media, Social Networking, Twitter, Facebook, Instagram, Forums and Blogging) and gambling (Gambling, Betting and Casino). Each of the search terms representing social media platforms was paired with each of the terms representing gambling to yield a total of 21 searches which were conducted on Google Scholar. Of these 21 search terms, 11 yielded useful articles and were subsequently used as search terms on the other three databases. All searches were conducted from $4^{\text {th }}$ August to the $3^{\text {rd }}$ of September 2020. A total of 3265 articles were searched by their titles and abstracts with 85 of those articles being identified as potentially relevant. Backward citation searching identified a further six articles yielding a total number of 91 articles. Grey literature (e.g. reports to gambling regulators, businesses) that were identified in databases and citation searches was included if it reported some form of primary data collection The full text of the remaining 89 articles was inspected, and 41 articles met our inclusion and exclusion criteria (Fig. 1).

\section{Exclusion Criteria}

The following exclusion criteria were applied to each of the 89 articles. Studies that were tangentially related to social media [17-19] or focused on similarity were excluded, as were papers that did not report primary data [13, 16, 20-22]. Papers that were duplicates (e.g. preprints) and not written in English were also excluded. In the case of duplicates, the peerreviewed version was selected for inclusion. After applying all the inclusion and exclusion criteria, a total of 41 articles were included in this narrative review.

\section{Results}

Across the 41 papers included in the systematic review, we synthesised them into three broad areas of study: communication, community and calculation of sentiment. These groupings are ad hoc however, and it is important to be aware that other parcellations exist (e.g. by audience, media content, motivation, perceptions of social media vs. actual social media data). The papers are summarised in Table 1 . The vast majority of the papers included have been published since 2015 (Fig. 2). 
Fig. 1 PRISMA flow chart of the systematic review
Search of electronic databases yielded: 3,265 articles which were then searched by title and abstracts.

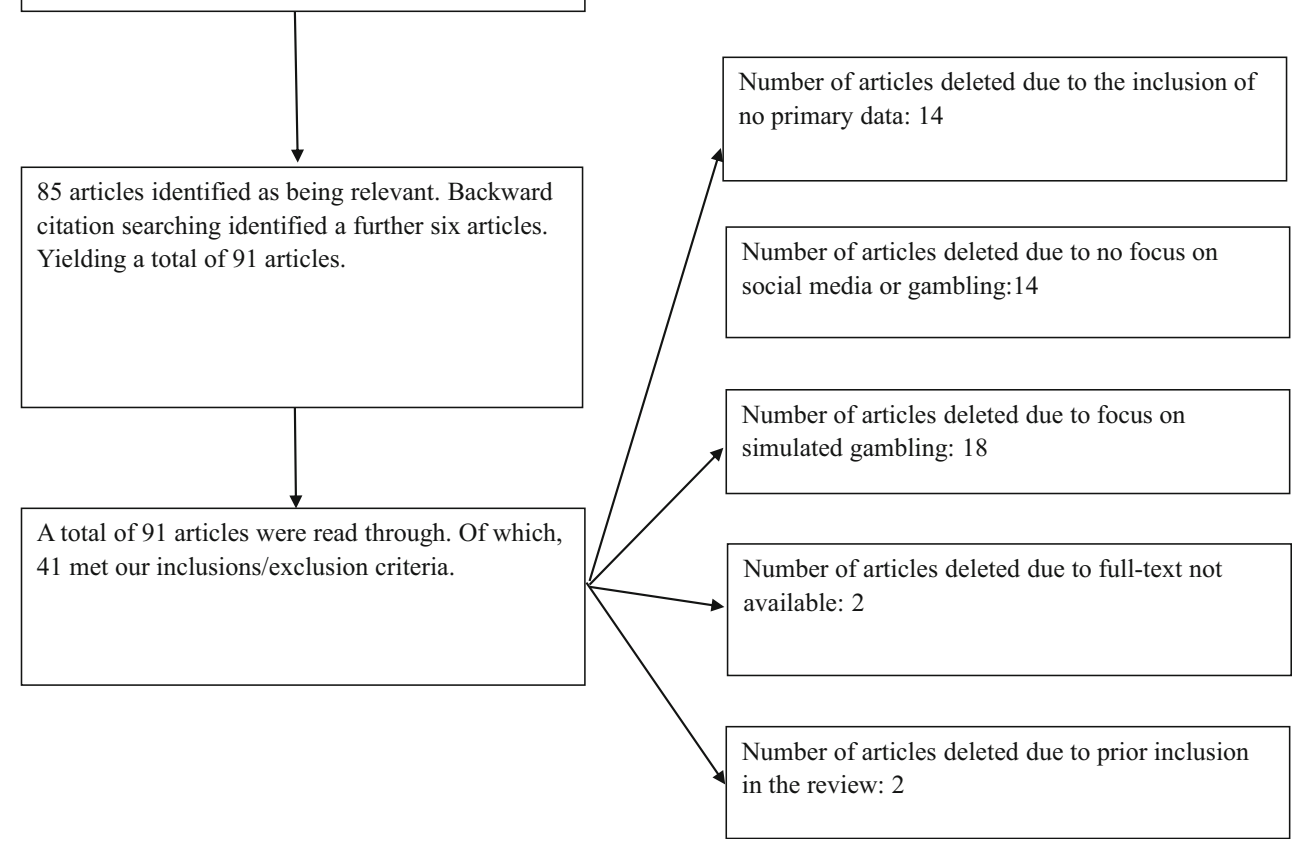

\section{Communication: Using Social Media to Advertise Gambling}

The first theme of the review was the use of social media by gambling companies to engage with consumers and promote their products and services. Research in this area addressed questions around the volume and reach of gambling companies via social media, what content gambling operators are posting, the underlying message behind this content, and the extent that vulnerable users of social media are exposed to gambling content.

One consistent finding was the reach that gambling companies can have across social media platforms, often having hundreds of thousands of followers $[7 \cdot \bullet, 24,28]$. Research also suggests that some betting companies post frequently throughout the day, although there is considerable variability between companies $[7 \bullet \bullet, 9 \bullet \bullet, 36,37]$. The large reach gambling operators have, and the potential to deliver high volumes of messaging via social media, allows gambling operators to maintain engagement with their products and raise awareness of their services in ways that conventional forms (i.e. newspaper, radio and television) of advertising cannot [26].

Gambling operators use numerous types of content to engage their audiences [7••, 30], and there is convergent evidence of certain types being common: promotion of gambling products, competition, sports news, customer engagement, betting tips, features, responsible gambling, and the use of humour $[8 \cdot \bullet, 24,34]$. One common finding across the articles reviewed was the paucity of responsible gambling messages, with some operators never posting responsible gambling messages, whilst others embedded the messages in small text at the foot of pictures $[7 \cdot \bullet, 9 \bullet \bullet, 24,34,36]$. Research has begun to look more closely at the different types of promotional content in social media posts such as in-play odds, cash out, free bet offers, requested odds, enhanced odds, bet builder and cash price competition [9*0]. In the content of the social media activity of British bookmakers, the most popular promotional content is requested odds, where consumers can build their own bets and gambling companies quote individualised odds back to them $[7 \cdot \bullet, 9 \bullet \cdot]$. Despite the higher potential payoff of these bets, they are rarely realised resulting in sizeable profit margins for book makers [35•].

Researchers have also looked at the underlying meaning within gambling content on social media, and found that there is a tendency to portray gambling advertisements in a positive, glamorous light, often minimising the potential losses whilst highlighting the potential for winnings $[7 \bullet \bullet, 23,32]$. Other occurring themes noted by some authors were adventure, mateship, normalisation of gambling, sexualised imagery and gendered framing of content [24, 28, 36], often segmented towards young men. It has been suggested that content, whether by design or happenstance, is framed in a way that would appeal to children with the use of bright colours, cartoon characters, sounds, animations and celebrities [32, 34]. 
Table 1 Studies included in the systematic review that have a communication focus

\begin{tabular}{|c|c|c|c|}
\hline Paper & Methodological approach & Key findings & Theme \\
\hline $\begin{array}{l}\text { Gainsbury et al. } \\
\text { (2016a) [23] }\end{array}$ & $\begin{array}{l}\text { Qualitative observation of social media } \\
\text { content from } 101 \text { operators }\end{array}$ & $\begin{array}{l}\text { Themes of gambling advertising on social media are positively } \\
\text { framed and rarely include responsible gambling information }\end{array}$ & $\begin{array}{l}\text { Communication- } \\
\text { advertising }\end{array}$ \\
\hline $\begin{array}{l}\text { Gainsbury et al. } \\
\text { (2016b) [24] }\end{array}$ & Online survey with 964 respondents & $\begin{array}{l}\text { Moderate/high-risk gamblers (PGSI 3+) saw and interacted with } \\
\text { more gambling advertising on social media. Also recalled more } \\
\text { responsible gambling content but less likely to act upon it }\end{array}$ & $\begin{array}{l}\text { Communication- } \\
\text { advertising }\end{array}$ \\
\hline $\begin{array}{l}\text { Thomas et al. } \\
\text { (2018) }[25 \bullet \bullet]\end{array}$ & $\begin{array}{l}\text { Mixed methods interviews (111 sports } \\
\text { fans) }\end{array}$ & $\begin{array}{l}\text { Young [11-16] basketball fans reported high (55\%) exposure to } \\
\text { gambling adverts on social media, particularly YouTube (36\%). } \\
\text { Attitudes towards gambling adverts were negative }\end{array}$ & $\begin{array}{l}\text { Communication- } \\
\text { advertising }\end{array}$ \\
\hline $\begin{array}{l}\text { Gainsbury et al. } \\
\text { (2015) [26] }\end{array}$ & Interviews (19 operators) & $\begin{array}{l}\text { Operators view social media positively with focused presence. } \\
\text { Main aims were brand awareness and engagement, limited } \\
\text { responsible gambling focus }\end{array}$ & $\begin{array}{l}\text { Communication- } \\
\text { advertising }\end{array}$ \\
\hline $\begin{array}{l}\text { Kaakinen et al. } \\
(2020)[27 \bullet]\end{array}$ & $\begin{array}{l}\text { Vignette study via online survey }(1430 \\
\text { respondents) }\end{array}$ & $\begin{array}{l}\text { Young people preferred antigambling social media vignettes, but } \\
\text { moderated by gambling attitudes }\end{array}$ & $\begin{array}{l}\text { Communication- } \\
\text { advertising }\end{array}$ \\
\hline $\begin{array}{l}\text { Miller et al. } \\
\text { (2016) [28] }\end{array}$ & $\begin{array}{l}\text { Webscraping and qualitative analysis } \\
\text { (877 Twitter users) }\end{array}$ & $\begin{array}{l}\text { Gambling is highly visible on social media with multiple purposes. } \\
\text { Forums provided a source of gambling support }\end{array}$ & $\begin{array}{l}\text { Communication- } \\
\text { advertising and } \\
\text { community- } \\
\text { help-seeking }\end{array}$ \\
\hline $\begin{array}{l}\text { O’Loughlin and } \\
\text { Blaszczynski } \\
\text { (2017) [29] }\end{array}$ & Experiment (120 participants) & $\begin{array}{l}\text { Adverts on social media posted by gambling operators increased } \\
\text { gambling attitudes and intentions compared to print and peer } \\
\text { posted content }\end{array}$ & $\begin{array}{l}\text { Communication- } \\
\text { advertising }\end{array}$ \\
\hline $\begin{array}{l}\text { Houghton et al. } \\
\quad(2018)[8 \cdot \bullet]\end{array}$ & Webscraping (of 13,344 tweets) & $\begin{array}{l}\text { Gambling affiliates' tweets tended to be more directly gambling } \\
\text { focused than gambling operators, which included general sports } \\
\text { and humourous content }\end{array}$ & $\begin{array}{l}\text { Communication- } \\
\text { advertising }\end{array}$ \\
\hline $\begin{array}{l}\text { Behmann (2013) } \\
\quad[30]\end{array}$ & Online survey (111 respondents) & $\begin{array}{l}\text { Gamblers found social media advertising useful for getting news, } \\
\text { entertainment and special offers, and as a form of two-way } \\
\text { communication }\end{array}$ & $\begin{array}{l}\text { Communication- } \\
\text { advertising }\end{array}$ \\
\hline $\begin{array}{l}\text { Bradley and } \\
\text { James }(2019) \\
{[7 \bullet \bullet]}\end{array}$ & Webscraping (of 63,913 tweets) & $\begin{array}{l}\text { UK bookmakers engage in extensive use of Twitter, with different } \\
\text { purposes (inward vs outward engagement) and heavy positive } \\
\text { sentiment bias }\end{array}$ & $\begin{array}{l}\text { Communication- } \\
\text { advertising }\end{array}$ \\
\hline $\begin{array}{l}\text { Jacques et al. } \\
\text { (2016) [31] }\end{array}$ & $\begin{array}{l}\text { Observational (examination of } 100 \\
\text { popular Facebook games) }\end{array}$ & $\begin{array}{l}\text { Heavy use of simulated gambling content in social media games, } \\
\text { and companies that made real money gambling games made } \\
\text { more non-casino gambling references }\end{array}$ & $\begin{array}{l}\text { Communication- } \\
\text { advertising }\end{array}$ \\
\hline $\begin{array}{l}\text { Ginnis and Kitson } \\
\text { (2020) [32] }\end{array}$ & $\begin{array}{l}\text { Webscraping (of followers to } \\
\text { bookmakers' accounts) }\end{array}$ & $\begin{array}{l}\text { Around } 6 \% \text { of bookmakers' (and } 17 \% \text { of esports gambling) } \\
\text { followers are from underage accounts. } 66 \% \text { of youths had seen } \\
\text { gambling adverts on social media }\end{array}$ & $\begin{array}{l}\text { Communication- } \\
\text { advertising }\end{array}$ \\
\hline $\begin{array}{l}\text { Djohari et al. } \\
\text { (2019) [33•] }\end{array}$ & $\begin{array}{l}\text { Mixed methods interviews (of } 170 \\
\text { participants) }\end{array}$ & $\begin{array}{l}\text { Around } 40 \% \text { of adults and children exposed to gambling adverts } \\
\text { via social media }\end{array}$ & $\begin{array}{l}\text { Communication- } \\
\text { advertising }\end{array}$ \\
\hline $\begin{array}{l}\text { Thomas et al. } \\
\text { (2015) [34] }\end{array}$ & $\begin{array}{l}\text { Observational mixed methods (of } \\
\text { bookmakers' social media posts) }\end{array}$ & $\begin{array}{l}\text { Monitored bookmakers' posts, finding high volume of posts along } \\
\text { different themes (e.g. riskiness, humour, appeal to men, offers) }\end{array}$ & $\begin{array}{l}\text { Communication- } \\
\text { advertising }\end{array}$ \\
\hline $\begin{array}{l}\text { Newall et al. } \\
\quad(2020)[35 \bullet]\end{array}$ & $\begin{array}{l}\text { Webscraping and online survey (of } \\
2889 \text { tweets, and } 55 \text { of the users who } \\
\text { tweeted them) }\end{array}$ & $\begin{array}{l}\text { Punters' requested bets via Twitter had high potential payoff but } \\
\text { much larger profit margins for bookmakers }\end{array}$ & $\begin{array}{l}\text { Communication- } \\
\text { advertising }\end{array}$ \\
\hline $\begin{array}{l}\text { Sproston et al. } \\
\text { (2015) [36] }\end{array}$ & $\begin{array}{l}\text { Observational and survey (of social } \\
\text { media adverts, and } 3200 \\
\text { respondents) }\end{array}$ & $\begin{array}{l}\text { Social media adverts were segmented, and users noticed use of } \\
\text { profiling and tracking. Survey respondents reported prevalent } \\
\text { exposure to adverts on social media }\end{array}$ & $\begin{array}{l}\text { Communication- } \\
\text { advertising }\end{array}$ \\
\hline $\begin{array}{l}\text { Stradder and } \\
\text { Naraine (2020) } \\
\text { [37] }\end{array}$ & $\begin{array}{l}\text { Webscraping (qualitative analysis of } \\
16,466 \text { tweets) }\end{array}$ & $\begin{array}{l}\text { Identifies multiple themes of operators tweets: sports, betting } \\
\text { language, location, influencers, sub-brands, cricket and action } \\
\text { words }\end{array}$ & $\begin{array}{l}\text { Communication- } \\
\text { advertising }\end{array}$ \\
\hline $\begin{array}{l}\text { Killick and } \\
\text { Griffiths (2019) } \\
\text { [9••] }\end{array}$ & $\begin{array}{l}\text { Webscraping (qualitative analysis of } \\
3375 \text { tweets) }\end{array}$ & $\begin{array}{l}\text { High variability in operators' Twitter activity and limited use of } \\
\text { responsible gambling messaging. Identified multiple categories } \\
\text { of promotion, of which requesting bets most popular }\end{array}$ & $\begin{array}{l}\text { Communication- } \\
\text { advertising }\end{array}$ \\
\hline $\begin{array}{l}\text { Hornle et al. } \\
\text { (2019) }[38 \bullet \bullet]\end{array}$ & Interviews of 35 operators & $\begin{array}{l}\text { Identifies issues with regulating social media advertising- } \\
\text { unethical use of targeted ads, and use of intermediaries } \\
\text { (influencers, affiliates) to promote commercial content }\end{array}$ & $\begin{array}{l}\text { Communication- } \\
\text { advertising }\end{array}$ \\
\hline $\begin{array}{l}\text { Gambling } \\
\text { Commission } \\
\text { (2017) [39] }\end{array}$ & Online survey (of 2803 respondents) & $\begin{array}{l}\text { Found high levels of exposure to gambling adverts in young } \\
\text { people, that around } 10 \% \text { follow a gambling social media } \\
\text { account, but limited evidence for a direct impact }\end{array}$ & $\begin{array}{l}\text { Communication- } \\
\text { advertising }\end{array}$ \\
\hline
\end{tabular}


Fig. 2 Graph of the number of papers included in the systematic review published each year

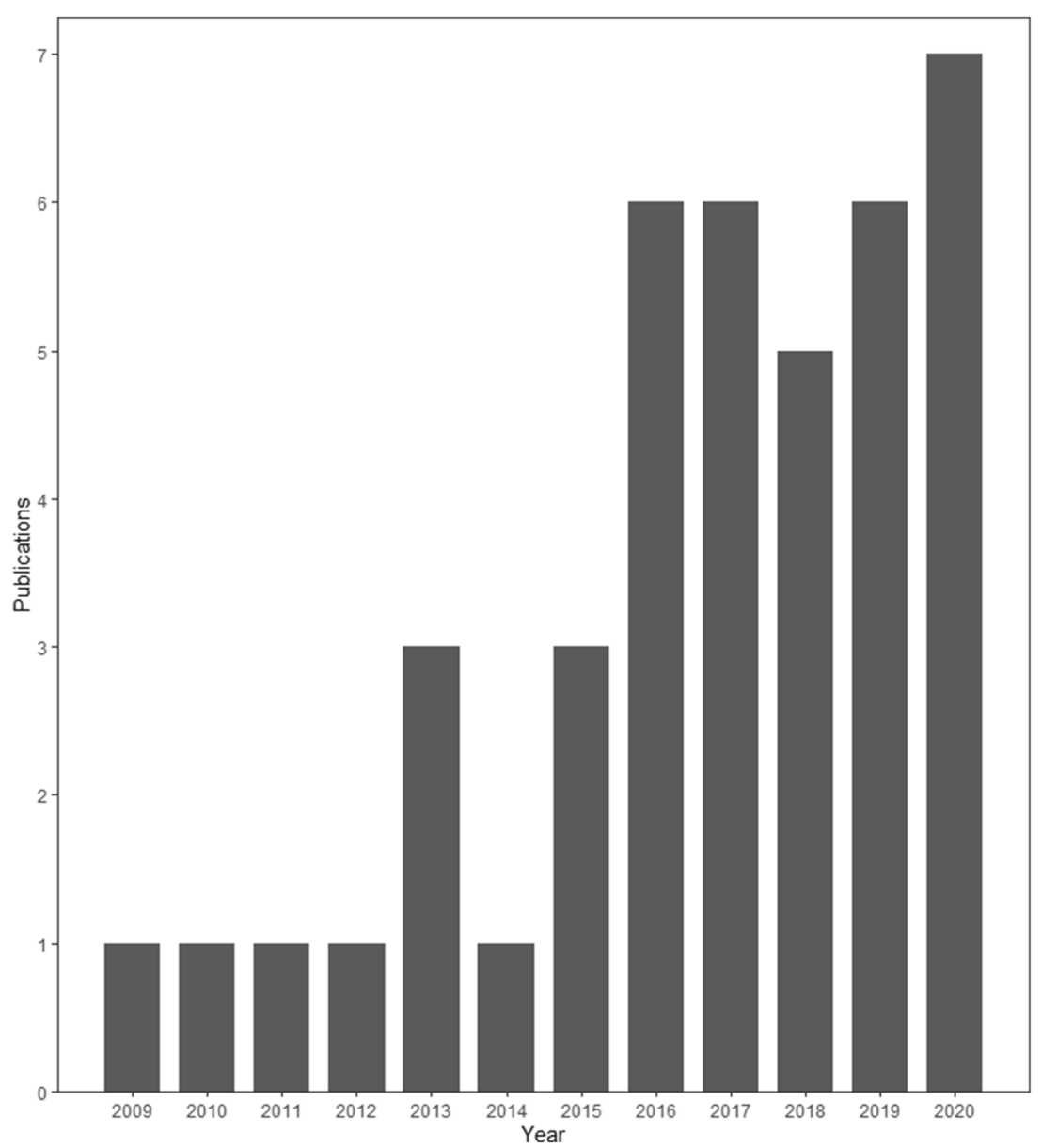

These findings highlight the importance of considering where gambling content is placed within social media, and to what extent vulnerable groups like young people (i.e. too young to gamble) or those with gambling problems are exposed to these messages. The UK Gambling Commission found that $70 \%$ of young people had been exposed to gambling adverts through social media [39]. It also reports that around $10 \%$ of young people follow a gambling account on YouTube, Instagram or Facebook [39]. A subsequent report found that around $66 \%$ of young people were exposed to gambling advertisements via social media [32]. Attempts to profile and classify followers of bookmakers' accounts suggest that around $6 \%$ of their followers were young people, which rises to $17 \%$ of followers on esports gambling accounts [32]. A review of leading Facebook games identified that references to gambling were common (in addition to simulate gambling content), most often for slot machines [31]. Young people are particularly at risk of exposure on social media if they are male and are sports fans [25••, 33•]. The increased opportunity for segmentation and targeting the most receptive audiences that social media offers advertisers, may risk capturing users who for regulatory (e.g. under the age of 18) or corporate responsibility (e.g. at risk of harm) purposes would be of concern. As the evidence evolves it may be that gambling regulators see a need to intervene and set guidelines for the profiling of social media users.

Whilst the impact of young people viewing gambling adverts is still to be determined, we do know that those who report higher risks of problematic gambling are more likely to report increased gambling intentions and behaviours after viewing gambling adverts on social media [17], as are people who have positive gambling attitudes [27•]. There is some early evidence that adverts on social media might foster positive attitudes toward gambling [29]. Despite the risk of exposure to young people, and the potential harm to those already vulnerable, the main forms of protection currently being deployed by social media companies and gambling companies appear to be using geolocation, age verification and taking down unsuitable adverts, all of which have their vulnerabilities [38••]. Additionally there is the complication that social media companies and gambling operators often reside in separate jurisdictions to users, which raises regulatory implications regarding the responsibility for safeguarding and the risk of exposure to unregulated gambling products. One recommendation has been that a different approach is required, 
based on consumer protection rather than gambling regulation that incorporates social media providers rather than placing the onus solely on gambling providers $[38 \bullet \bullet]$.

\section{Community: Gambling Forums as Places of Support or Recreation}

The second theme was the use of data from gambling forums, which can be divided into forums where users either seek support and advice from fellow gamblers, or share tips and gambling strategies with each other.

Gambling support forums are popular sources of support that have the advantage of being accessible $24 / 7$ and providing anonymous support to those who experience gambling difficulties. These are aimed at the gambler themselves or those affected by the gambler (e.g. family, friends) $[10 \bullet$, 28]. Several papers using observational, ethnographic and big data techniques have identified that posts can be categorised into: resources to aid recovery (formal and informal), supportive messages, personal stories, requests for help or specific questions, introductions and moderator messages, financial resources and support, impact on family and relationships, and expressing and managing negative emotions of shame and guilt [10••, 40-42].

In addition, analyses of the content of forum posts, and in some cases surveying forum users, have sought to discover and understand the benefits and potential drawbacks support forum usage has on its members. The use of support forums has been reported to reduce loneliness, enhance a sense of identity, increase self-knowledge, manage impulses to gamble, and enhance the range of strategies to manage gambling thoughts and behaviours [40, 41, 43・•]. However, gambling forums do pose a number of challenges. For example, users have criticised moderators for being too slow to take down abusive posts or respond to those in crisis [28, 41]. Equally, whilst they can offer helpful and useful advice from those who have expertise from experience, the support is not from qualified professionals [28]. There is tradeoff here between availability and lived experience, and established efficacy. Nonetheless there are encouraging indications that online support forums provide an important source of support to those struggling with gambling experiences and do considerably well despite the lack of resources and funding available.

Research on recreational gambling forums has explored the characteristics of the people who use these forums, and has helped to illuminate the types of posts made to these forums. Users of gambling forums are younger, typically male, heavier users of the internet, and are likely to already be classified as at risk or probable pathological gamblers [44-46]. There is mixed evidence that they might be more lonely from a subsample analysis [45]. Users of gambling forums reported greater use of payday loans and using online (real-money) casino sites, but were less likely to visit gambling support forums [44]. Posts onto these recreational gambling forums were related to gambling experiences, gambling tips/strategies and gambling news [44, 47]. In-depth analysis of an online poker forum found two themes consisting of subjective experience of playing poker, and developing their poker skills, in terms of both the mathematical probability of playing, and the psychological control of themselves and other poker players strategies [48]. Whilst research has detailed the types of people who use pro-gambling forums and the type of content they post about, it is less clear what if anything can be done to help these at risk users from developing or continuing potentially harmful gambling behaviours. Equally, more needs to be done to understand the long-term efficacy of using and participating in an online forum to help manage gambling problems.

\section{Calculation: The Wisdom of Crowds}

The third theme that emerged involves the use of social media data to gauge the sentiment of people posting about events that can be bet upon such as sporting matches. Sentiment in these instances refers to the emotional valence social media users display in their postings or engagement towards an outcome. This is then used to predict the outcome of those events. Social media is essentially harnessed as a naïve prediction market, and compared against predictions derived from models such as ELO, or expert judgements such as bookmakers' odds. A second aim of studies in this theme was to test whether these aggregated data provide additional informational value over bookmakers' judgements and if they can be used to develop a profitable betting strategy. The majority of the research in this area studies sports (i.e. NFL, NBA, English Premier League) but has also been applied to esports and politics $[49,50]$.

The papers in this field took a few approaches to modelling sentiment. Typically this involved using Twitter posts as their main source of data $[50,51 \bullet \cdot 52,53 \cdot \bullet]$, but some used specialised sports prediction websites or communities such as Transfermarkt [54•,55•]. Others used likes or follows on social media as a measure of popularity to operationalise sentiment bias $[49,56 \cdot 57]$. Others have further tried to distinguish between absolute and relative sentiment, finding that changes in relevant sentiment have particular value in successfully predicting outcomes, and also where upsets are likely to occur.

Most papers in this area have compared various ways of operationalising sentiment against odds set by a bookmaker. Even under the most advantageous circumstances, these found sentiment to perform at a similar level of accuracy to bookmakers' odds, i.e. both predicted the final outcome of a sporting match at the same rate of success. In many cases, sentiment was less predictive of outcomes than odds. However, a common finding that emerged was the ability of sentiment to pick up on longshot outcomes to occur. When setting odds on an outcome, bookmakers have to balance their own calibration of the probabilities of certain outcomes occurring, whilst 
at the same time creating a set of bets that are attractive to potential consumers. Where sentiment appeared to be particularly effective was in identifying the likelihood of an upset $[53 \bullet \bullet, 58]$. The ability of sentiment to predict upsets is important in understanding these might be profitable. Where sentiment-based approaches seem to have particular value is in their ability to identify successful upsets.

The other caveat noted in some of these analyses is that the predictive value of these may vary over time - in particular a couple of analyses [52, 59] found that using social media had particular predictive value in the latter half of sports seasons. Further, it appears one of the areas where social media data has particular value is in its immediacy; sentiment on social media moves faster than the changing odds of a bookmaker, and it appears that in certain instances, this immediacy has particular value.

\section{Discussion}

Social media is being used in gambling research to study how gambling companies communicate, how gambling communities develop and how sentiment can be calculated and harnessed to predict outcomes. The majority of these papers have been published in the last 5 years, from a diverse range of areas including gambling studies, economics, data science and sociology. The literature calculating sentiment has clear relevance to gambling but has been exclusively published in outlets unrelated to gambling studies. There are a number of areas that are worth highlighting where social media can be used in future gambling research.

\section{New Platforms and Multimedia}

It is important to be aware of the evolving ways in which people communicate on social networking sites and the increasing use of multimedia. At present, the literature has been mostly focused on text posted by gambling companies or users on Facebook and Twitter, which is representative of the way in which companies use social media [26]. However, social media increasingly involves the use of images, sound and videos, with some popular platforms such as Instagram and TikTok centred around these. Indeed, it has been previously noted that the majority of some gambling companies' postings on Twitter include images [7••]. This critical gap in understanding the use of multimedia in gambling advertising warrants examination, and the analysis of image data remains a rich yet untapped source of data for gambling researchers. However, there are methodological challenges in processing these data. It is possible that classification approaches in machine learning can be used to classify images and multimedia at scale. This involves the training of a dataset based on a prior categories or themes, which can be built from rich, nuanced qualitative work, and applying them to a large novel set of data.

\section{The Impact on Vulnerable Groups}

One area of concern warranting further examination is the visibility of, and engagement with, gambling adverts on social media by people too young to legally gamble. There is early albeit converging evidence that many children see gambling adverts on social media [25••, 33•, 39]. Further, a small proportion of followers of gambling companies' social media profiles appear to be children as well [32]. It is important to note that gambling operators report wanting, alongside their regulatory obligations, to prevent young people from inadvertently accessing their social media profiles [26]. Nonetheless, does indicate that there is a need for further study, perhaps by using simulated social media profiles, to examine the ways in which social media advertising reaches younger people. The difficulty with looking at this solely from the perspective of the profiles of gambling companies is that this does not necessarily correspond to what the account's followers see on their profile. Social media companies often have algorithms to filter the content users receive. Two users who follow the same gambling company on Twitter can be shown different volumes and types of content, based on variables such as the amount of accounts they follow, engagements with content in their network, or previous engagement with gambling content. Therefore there is a need to understand this heterogeneity, and its impact, from the perspective of the user. Studies that have analysed the advertising content on social media have noted the lack of responsible gambling messaging $[7 \bullet \bullet, 9 \bullet \bullet]$. Further research ought to determine the extent that there are differences between advertising on traditional and emerging platforms.

\section{Diversity (of Communities)}

Relevant to the use of new platforms and potentially vulnerable groups is the role of intermediaries such as affiliates, tipsters and influencers including celebrities. Whereas gambling companies report more focused social media presences [26], intermediaries are likelier to use a range of social media platforms, which include ones with greater multimedia usage. They operate in an ambiguous legal area and might be more likely to engage younger audiences $[8 \bullet \bullet, 38 \bullet \cdot]$. There is also a blurred line between content generated by influencers and commercial content that is worth rigorous study.

Further, there are many communities, groups and stakeholders involved in gambling, many of whom are active on social media and hitherto unexamined. Understanding the way social media is used for other gambling related issues is of further interest, especially in the interplay between various gambling stakeholders and policy [28]. This comes into sharpest focus when looking at communities of recreational 
Table 2 Studies included in the systematic review that have a community (recreational or help-seeking) focus

\begin{tabular}{|c|c|c|c|}
\hline Paper & Methodological approach & Key findings & Theme \\
\hline $\begin{array}{l}\text { Sirola et al. (2019) } \\
\quad[45]\end{array}$ & Online survey (2642 respondents) & $\begin{array}{l}\text { Higher SOGS severity, internet use and male gender linked } \\
\text { with online gambling forum use, with evidence in one } \\
\text { sample of moderation by loneliness }\end{array}$ & $\begin{array}{l}\text { Community- } \\
\text { recreational }\end{array}$ \\
\hline $\begin{array}{l}\text { Miller et al. (2016) } \\
\quad[28]\end{array}$ & $\begin{array}{l}\text { Webscraping and qualitative analysis } \\
\text { (877 Twitter users) }\end{array}$ & $\begin{array}{l}\text { Gambling is highly visible on social media with multiple } \\
\text { purposes. Forums provided a source of gambling } \\
\text { support }\end{array}$ & $\begin{array}{l}\text { Communication- } \\
\text { advertising and } \\
\text { community- } \\
\text { help-seeking }\end{array}$ \\
\hline $\begin{array}{l}\text { Sirola et al. (2018) } \\
\quad[44]\end{array}$ & Online survey (1200 respondents) & $\begin{array}{l}\text { Higher problem gambling severity (SOGS), male gender, } \\
\text { age, online casino use, payday loan use and compulsive } \\
\text { internet use associated with online gambling forum use }\end{array}$ & $\begin{array}{l}\text { Community- } \\
\text { recreational }\end{array}$ \\
\hline $\begin{array}{l}\text { Rodda et al. (2018) } \\
{[43 \cdot \bullet]}\end{array}$ & Qualitative (of 1370 forum posts) & $\begin{array}{l}\text { Found four types of change strategies (pre-decisional, } \\
\text { pre-actional, actional, multi-phased) from posts to an } \\
\text { online support forum }\end{array}$ & Community — support \\
\hline $\begin{array}{l}\text { Floros et al. (2013) } \\
\quad[46]\end{array}$ & Online survey (2017 respondents) & $\begin{array}{l}\text { Identified that internet usage, particularly of social media, } \\
\text { correlated with adolescent online gambling }\end{array}$ & $\begin{array}{l}\text { Community- } \\
\text { recreational }\end{array}$ \\
\hline $\begin{array}{l}\text { Wood and Wood } \\
\text { (2009) [41] }\end{array}$ & $\begin{array}{l}\text { Mixed methods (analysis of } 60 \text { forum } \\
\text { posts, } 19 \text { interviews and online } \\
\text { survey of } 121 \text { participants) }\end{array}$ & $\begin{array}{l}\text { Identified different motivations for forum posting (advice, } \\
\text { help-seeking, stories, supporting others), and how } \\
\text { forums built a sense of community by people with } \\
\text { gambling problems }\end{array}$ & Community — support \\
\hline $\begin{array}{l}\text { Bradley and James } \\
\quad(2020)[10]\end{array}$ & $\begin{array}{l}\text { Webscraping of } 2298 \text { posts to a } \\
\text { gambling form }\end{array}$ & $\begin{array}{l}\text { Statistical modelling identified four categories of topic- } \\
\text { negative emotions caused by gambling, recovery } \\
\text { resources, gambling products and financial support }\end{array}$ & Community — support \\
\hline $\begin{array}{l}\text { Jarvinen-Tassopoulos } \\
\quad(2020)[42]\end{array}$ & $\begin{array}{l}\text { Qualitative study of } 97 \text { posts by } 40 \text { users } \\
\text { to a support forum for family } \\
\text { members affected by gambling }\end{array}$ & $\begin{array}{l}\text { Themes of help-seeking, shame and trust issues, managing } \\
\text { the gambling problem financially and motivations or } \\
\text { barriers in family life }\end{array}$ & Community—support \\
\hline $\begin{array}{l}\text { Parke and Griffiths } \\
\quad \text { (2011) [47] }\end{array}$ & $\begin{array}{l}\text { Online ethnography of two online poker } \\
\text { forums }\end{array}$ & $\begin{array}{l}\text { Two themes relating to the experience of online poker play, } \\
\text { and skill development emerged from ethnography of } \\
\text { forum use }\end{array}$ & $\begin{array}{l}\text { Community- } \\
\text { recreational }\end{array}$ \\
\hline $\begin{array}{l}\text { Mudry and Strong } \\
\text { (2013) [40] }\end{array}$ & $\begin{array}{l}\text { Discourse analysis of } 11 \text { gambling } \\
\text { support forum users }\end{array}$ & $\begin{array}{l}\text { Identified themes relating to forum posts (shame, harm, } \\
\text { gambling as an addiction, recovery, and control or } \\
\text { responsibility) and forum usage (moderation, } \\
\text { introduction, sharing stories and experience, } \\
\text { help-seeking and venting) }\end{array}$ & Community—support \\
\hline $\begin{array}{l}\text { O’Leary and Carroll } \\
\text { (2012) [48] }\end{array}$ & $\begin{array}{l}\text { Online ethnography of three online } \\
\text { poker forums }\end{array}$ & $\begin{array}{l}\text { Examined hierarchies within and between online poker } \\
\text { forums, the sense of community within each of them, } \\
\text { and how gameplay related topics have influenced how } \\
\text { people play poker online and offline }\end{array}$ & $\begin{array}{l}\text { Community- } \\
\text { recreational }\end{array}$ \\
\hline
\end{tabular}

gamblers, which has been limited to the online poker community $[47,48]$. It is worth pointing out that there are a wealth of other gambling communities that have not been explored. Although most of the focus in the communication and calculation of sentiment themes has fallen onto the betting sector, this has not been replicated in understanding the dynamics of the many betting communities that exist.

\section{Longitudinal Research}

Across each of the themes, there is potential in further harnessing the longitudinal nature of these data. The content of gambling advertisements for a sporting event will change as the event draws near. The makeup and topics of conversation of discussion groups evolve over months or years, and as information comes in sentiment data might become biased in the same way we see behaviour in stock markets [60].
Similarly within the theme of community, one of the topics that emerged was the issue of recovery, and particularly recovery as a process. The study of recovery is by its nature a longitudinal process, and exploring how users' posts on social media change over time might give insight into how gambling support communities facilitate recovery, which has the potential to be scaled up and used for wider benefit. There are also important ethical considerations around the observation and use of data from gambling communities, and approaches that minimise intrusion (e.g. using statistical models to model topics) and/or maximise transparency (e.g. engaging with the group) are desirable.

\section{Replicability}

Across all of the themes, there is early encouraging evidence of convergence in studies looking at issues such as advertising 
Table 3 Studies included in the systematic review that focus on the calculation theme

\begin{tabular}{|c|c|c|c|}
\hline Paper & Methodological approach & Key findings & Theme \\
\hline $\begin{array}{l}\text { Feddersen et al. (2017) } \\
\quad[57]\end{array}$ & $\begin{array}{l}\text { Observational (likes on } \\
\text { Facebook pages of major } \\
\text { sports teams) }\end{array}$ & $\begin{array}{l}\text { Finds evidence of sentiment bias in bookmakers' odds setting using } \\
\text { Facebook likes as a proxy for investor sentiment }\end{array}$ & $\begin{array}{l}\text { Calculation- } \\
\text { wisdom of } \\
\text { crowds }\end{array}$ \\
\hline $\begin{array}{l}\text { Brown et al. }(2017) \\
{[51 \bullet \bullet]}\end{array}$ & $\begin{array}{l}\text { Webscraping (of } 13.8 \text { million } \\
\text { tweets) }\end{array}$ & $\begin{array}{l}\text { Twitter posts can predict the outcome of soccer matches, with particular } \\
\text { value after goals and red cards, and this can provide additional } \\
\text { information over and above odds }\end{array}$ & $\begin{array}{l}\text { Calculation- } \\
\text { wisdom of } \\
\text { crowds }\end{array}$ \\
\hline $\begin{array}{l}\text { Feddersen, Humphreys } \\
\text { and Soebbing }(2020) \\
{[56 \cdot]}\end{array}$ & $\begin{array}{l}\text { Observational (of sports teams } \\
\text { Facebook likes) }\end{array}$ & $\begin{array}{l}\text { Finds evidence for sentiment bias in betting behaviour for NFL but not } \\
\text { NBA games based on likes }\end{array}$ & $\begin{array}{l}\text { Calculation- } \\
\text { wisdom of } \\
\text { crowds }\end{array}$ \\
\hline $\begin{array}{l}\text { Hong and Skiena (2010) } \\
\text { [52] }\end{array}$ & Webscraping (of Twitter) & $\begin{array}{l}\text { Sentiment (from Twitter) performs less well at predicting NFL outcomes } \\
\text { compared to performance stats, but sentiment-based betting can be } \\
\text { profitable }\end{array}$ & $\begin{array}{l}\text { Calculation- } \\
\text { wisdom of } \\
\text { crowds }\end{array}$ \\
\hline $\begin{array}{l}\text { Williams and Reade } \\
\text { (2016) [50] }\end{array}$ & $\begin{array}{l}\text { Webscraping (of } 78,147 \\
\text { tweets) }\end{array}$ & $\begin{array}{l}\text { Evidence of market inefficiency in betting markets, as they respond } \\
\text { slowly to events being discussed on social media }\end{array}$ & $\begin{array}{l}\text { Calculation- } \\
\text { wisdom of } \\
\text { crowds }\end{array}$ \\
\hline Godin et al. (2014) [59] & $\begin{array}{l}\text { Webscraping (of over } 50 \\
\text { million Tweets) }\end{array}$ & $\begin{array}{l}\text { A combination of Twitter based sentiment and predictions, and statistical } \\
\text { performance, can perform similarly in accuracy to betting odds and } \\
\text { prove more profitable, especially later on in a season }\end{array}$ & $\begin{array}{l}\text { Calculation- } \\
\text { wisdom of } \\
\text { crowds }\end{array}$ \\
\hline $\begin{array}{l}\text { Schumaker, Karmoszko } \\
\text { and Labedz Jr. (2016) } \\
\text { [58] }\end{array}$ & $\begin{array}{l}\text { Webscraping (of over } 1 \text { million } \\
\text { tweets) }\end{array}$ & $\begin{array}{l}\text { Attempted to decompose sentiment not just by valence, but by } \\
\text { objectivity-subjectivity. Models based on sentiment did not tend to be } \\
\text { more accurate than odds, but some were profitable by identifying } \\
\text { upsets }\end{array}$ & $\begin{array}{l}\text { Calculation- } \\
\text { wisdom of } \\
\text { crowds }\end{array}$ \\
\hline $\begin{array}{l}\text { Schumaker et al. (2017) } \\
{[53 \cdot \bullet]}\end{array}$ & Webscraping & $\begin{array}{l}\text { Used investing techniques to model absolute and relative sentiment, and } \\
\text { whilst relative sentiment was less accurate was more profitable due to } \\
\text { picking upsets }\end{array}$ & $\begin{array}{l}\text { Calculation- } \\
\text { wisdom of } \\
\text { crowds }\end{array}$ \\
\hline $\begin{array}{l}\text { Dagaev and Stoyan } \\
\text { (2020) [49] }\end{array}$ & $\begin{array}{l}\text { Observational (using Twitter } \\
\text { likes of esports teams) }\end{array}$ & $\begin{array}{l}\text { Uses Twitter followers to model popularity, finding biases in betting } \\
\text { behaviour based on popularity }\end{array}$ & $\begin{array}{l}\text { Calculation- } \\
\text { wisdom of } \\
\text { crowds }\end{array}$ \\
\hline $\begin{array}{l}\text { Brown and Reade (2019) } \\
\text { [55•] }\end{array}$ & Webscraping & $\begin{array}{l}\text { Finds pooled judgements using a sports tipster community can } \\
\text { outperform bookmakers' odds and has additional informational value }\end{array}$ & $\begin{array}{l}\text { Calculation- } \\
\text { wisdom of } \\
\text { crowds }\end{array}$ \\
\hline Peeters (2018) [54•] & Webscraping & $\begin{array}{l}\text { Transfermarkt valuations of players perform similarly to expert and } \\
\text { statistical judgements (ELO, FIFA, betting odds) }\end{array}$ & $\begin{array}{l}\text { Calculation- } \\
\text { wisdom of } \\
\text { crowds }\end{array}$ \\
\hline
\end{tabular}

content, frequencies and absences of responsible gambling messaging $[7 \bullet \bullet, 8 \bullet \bullet, 9 \bullet \bullet$, in topics on online communities [10••] and in the efficacy of sentiment to guide betting strategy $[52,58]$. There is however a need to establish the replicability of these findings, illustrated using the sentiment literature. A range of timeframes, volumes of data and implementations of sentiment have been used that give considerable scope to assess whether there is a most efficacious approach. Some appear to be more effective later in sports seasons, as sentiment and performance become calibrated [59]. Replications are needed to understand the boundary conditions on the effectiveness of sentiment in predicting the market. There is a risk that the effect size diminishes over time as bookmakers become more aware of these approaches and take sentiment into account, reducing the window for sentiment led betting opportunities. Thus there are multiple threats to the effectiveness of sentiment based approaches that warrant investigation.

\section{Limitations}

This review has categorised the studies of social media in gambling into three areas. This should be considered primarily for clarity of presentation. There are many nuances within each theme, such as the group of study (e.g. recreational vs problematic gamblers), type of gambling and research approach (e.g. quantitative vs qualitative, survey vs content analysis). Further, whilst we have identified broad similarities in findings between studies, these should be treated as indicative; the number of papers reviewed is relatively small and so most require further replication.

\section{Conclusions}

Research using social media data in gambling research can be categorised into three themes: communication, community 
and calculation (of sentiment). Social media has been used to study gambling advertising and the groups it reaches and the communities of gamblers that exist online and to aggregate sentiment as a betting tool. In each case, there are promising findings that in time might feed into policy, practice and recreational gambling behaviour (Tables 2, 3).

Availability of Data and Material Literature search files and summary of articles are available from the OSF https://osf.io/dme3s/.

Author's Contribution RJ is the guarantor. $\mathrm{RJ}$ and $\mathrm{AB}$ searched the databases, read over the manuscripts and drafted the manuscript. All authors read, provided feedback and approved the final version of the manuscript.

\section{Declaration}

Conflict of Interest The authors declare no competing interests.

Open Access This article is licensed under a Creative Commons Attribution 4.0 International License, which permits use, sharing, adaptation, distribution and reproduction in any medium or format, as long as you give appropriate credit to the original author(s) and the source, provide a link to the Creative Commons licence, and indicate if changes were made. The images or other third party material in this article are included in the article's Creative Commons licence, unless indicated otherwise in a credit line to the material. If material is not included in the article's Creative Commons licence and your intended use is not permitted by statutory regulation or exceeds the permitted use, you will need to obtain permission directly from the copyright holder. To view a copy of this licence, visit http://creativecommons.org/licenses/by/4.0/.

\section{References}

Papers of particular interest, published recently, have been highlighted as:

- Of importance

•. Of major importance

1. Griffiths M. Gambling on the internet: a brief note. J Gambl Stud. 1996;12(4):471-3.

2. Kaplan AM, Haenlein M. Users of the world, unite! The challenges and opportunities of social media. Bus Horizons. 2010;53(1):5968.

3. Ofcom. Adults' Media Use \& Attitudes Report 2020. London: Ofcom; 2020.

4. Wu S, Hofman JM, Mason WA, Watts DJ, editors. Who says what to whom on twitter. Proceedings of the 20th international conference on World wide web; 2011.

5. Leung XY, Bai B, Stahura KA. The marketing effectiveness of social media in the hotel industry: a comparison of Facebook and Twitter. J Hosp Tour Res. 2015;39(2):147-69.

6. Regulus Partners. Gambling advertising and marketing spend in Great Britain, 2014-2017: GambleAware; 2018 [Available from: https://about.gambleaware.org/media/1853/2018-11-24-rp-ga-gbmarketing-spend-infographic-final.pdf.

7.• Bradley A, James RJE. How are major gambling brands using Twitter? Int Gambl Stud. 2019;19(3):451-70 Comprehensive analysis of Twitter use of British bookmakers, and analyses the sentiment in the posts.

8.• Houghton S, McNeil A, Hogg M, Moss M. Comparing the Twitter posting of British gambling operators and gambling affiliates: a summative content analysis. Int Gambl Stud. 2019;19(2):312-26 Compares Twitter use of betting companies and affiliates.

9.• Killick EA, Griffiths MD. A content analysis of gambling operators. J Gambl Stud. 2020;36:319-41 Analyses content of operator tweets and categorises different types of promotion.

$10 . \bullet$ Bradley A, James RJE. Defining the key issues discussed by problematic gamblers on web-based forums: a data-driven approach. Int Gambl Stud. 2020:1-15 Uses webscraping and statistical modelling to identify topics of conversation in an online gambling support forum.

11. Melville KM, Casey LM, Kavanagh DJ. Psychological treatment dropout among pathological gamblers. Clin Psychol Rev. 2007;27(8):944-58.

12. Cooper G. Exploring and understanding online assistance for problem gamblers: the pathways disclosure model. 2004.

13. Sirola A, Savela N, Savolainen I, Kaakinen M, Oksanen A. The role of virtual communities in gambling and gaming behaviors: a systematic review. J Gambl Stud. 2020.

14. Gainsbury S, King D, Abarbanel B, Delfabbro P, Hing N. Convergence of gambling and gaming in digital media. Melbourne: Victorian Responsible Gambling Foundation; 2015.

15. Gainsbury S, King D, Delfabbro P, Hing N, Russell A, Blaszczynski A, et al. The use of social media in gambling: Gambling Research Australia; 2015.

16. Gainsbury SM, Hing N, Delfabbro PH, King DL. A taxonomy of gambling and casino games via social media and online technologies. Int Gambl Stud. 2014;14(2):196-213.

17. Hing N, Cherney L, Blaszczynski A, Gainsbury SM, Lubman DI. Do advertising and promotions for online gambling increase gambling consumption? An exploratory study. Int Gambl Stud. 2014;14(3):394-409.

18. Hing N, Sproston K, Brook K, Brading R. The structural features of sports and race betting inducements: issues for harm minimisation and consumer protection. J Gambl Stud. 2017;33(2):685-704.

19. Rockloff M, Browne M, Greer N, Armstrong T, Thorne H. Mobile EGM games: evidence that simulated games encourage real-money gambling. J Gambl Stud. 2019:1-13.

20. Delabbro PH, King D. 'It's concerning', but is it your concern? Objectivity, advocacy and activism in gambling research. Int Gambl Stud. 2020.

21. Houghton S, Moss M, Casey E. Affiliate marketing of sports betting - a cause for concern? Int Gambl Stud. 2020;20(2):240-5.

22. Griffiths M, King D, Delfabbro P. Adolescent gambling-like experiences: Are they a cause for concern? Educ Health. 2009;27(2):2730.

23. Gainsbury SM, Delfabbro P, King DL, Hing N. An exploratory study of gambling operators' use of social media and the latent messages conveyed. J Gambl Stud. 2016;32(1):125-41.

24. Gainsbury SM, King DL, Russell AM, Delfabbro P, Derevensky J, Hing N. Exposure to and engagement with gambling marketing in social media: reported impacts on moderate-risk and problem gamblers. Psychol Addict Behav. 2016;30(2):270-6.

25.• Thomas SL, Bestman A, Pitt H, Cassidy R, McCarthy S, Nyemcsok $\mathrm{C}$, et al. Young people's awareness of the timing and placement of gambling advertising on traditional and social media platforms: a study of 11-16-year-olds in Australia. Harm Reduct J. 2018;15(51):1-13 Young sports fans in Australia are regularly exposed to gambling advertisements via social media.

26. Gainsbury SM, King DL, Hing N, Delfabbro P. Social media marketing and gambling: an interview study of gambling operators in Australia. Int Gambl Stud. 2015;15(3):377-93. 
27. Kaakinen M, Sirola A, Savolainen I, Oksanen A. Young people and gambling content in social media: An experimental insight. Drug Alcohol Rev. 2020;39(2):152-61 Identifies how gambling attitudes affect responses to gambling advertising.

28. Miller C, Krasodomski-Jones A, Smith J. Gambling \& Social Media. London: Demos; 2016.

29. O'Loughlin I, Blaszczynski A. Comparative effects of differing media presented advertisements on male youth gambling attitudes and intentions. Int J Ment Heal Addict. 2018;16:313-27.

30. Behmann M. Analysis of the role of social media marketing and communication in the online gambling market: University of Malta; 2013.

31. Jacques C, Fortin-Guichard D, Bergeron P-Y, Boudreault C, Lévesque D, Giroux I. Gambling content in Facebook games: a common phenomenon? Comput Hum Behav. 2016;57:48-53.

32. Ginnis S, Kitson $\mathrm{H}$. The impact of gambling marketing and advertising on children, young people and vulnerable adults. London: Ipsos MORI; 2020.

33. Djohari N, Weston G, Cassidy R, Wemyss M, Thomas S. Recall and awareness of gambling advertising and sponsorship in sport in the UK: a study of young people and adults. Harm Reduct J. 2019;16(1):24 Gambling advertising is common on social media and viewed as intrusive.

34. Thomas SL, Bestman A, Pitt H, Deans EG, Randle MJ. The marketing of wagering on social media: an analysis of promotional content on YouTube, Twitter and Facebook. Victoria: Victorian Responsible Gambling Foundation; 2015.

35. Newall PWS, Walasek L, Kiesel RV, Ludvig EA, Meyer C. Request-a-bet sports betting products indicate patterns of bettor preference and bookmaker profits. J Behav Addict. 2020; Demonstrates that the types of bet requested by punters have a significant house edge.

36. Sproston K, Hanley C, Brook K, Hing N, Gainsbury SM. Marketing of Sports Betting and Racing. Melbourne: Gambling Research Australia; 2015.

37. Stadder E, Naraine ML. Place your bets: an exploratory study of sports-gambling operators. Int J Sport Commun. 2020;13(2).

38.• Hornle J, Schmidt-Kessen M, Littler A, Padumadsa E. Regulating online advertising for gambling - once the genie is out of the bottle ... Inf Commun Technol Law. 2019;28(3):311-34 Explores contemporary issues regarding the law for gambling advertising on social media.

39. The Gambling Commission. Young people and gambling 2017. Birmingham: The Gambling Commission; 2017.

40. Mudry TE, Strong T. Doing recovery online. Qual Health Res. 2012;23(3):313-25.

41. Wood RTA, Wood SA. An evaluation of two United Kingdom online support forums designed to help people with gambling issues. J Gambling Issues. 2009;23.

42. Jarvinen-Tassopoulos J. The impact of problem gambling: are there enough services available for families with children? Public Health. 2020;184:28-32.

43.• Rodda SN, Hing N, Hodgins DC, Cheetham A, Dickins M, Lubman DI. Behaviour change strategies for problem gambling: an analysis of online posts. Int Gambl Stud. 2018;18(3):420-38 Identifies different change strategies discussed on online gambling forums, and where they are temporally situated.
44. Sirola A, Kaakinen M, Oksanen A. Excessive gambling and online gambling communities. J Gambl Stud. 2018;34(4):1313-25.

45. Sirola A, Kaakinen M, Savolainen I, Oksanen A. Loneliness and online gambling-community participation of young social media users. Comput Hum Behav. 2019;95:136-45.

46. Floros GD, Siomos K, Fisoun V, Geroukalis D. Adolescent online gambling: the impact of parental practices and correlates with online activities. J Gambl Stud. 2013;29(1):131-50.

47. Parke A, Griffiths MD. Poker gambling virtual communities: the use of computer-mediated communication to develop cognitive poker gambling skills. Int J Cyber Behav Psychol Learn (IJCBPL). 2011;1(2):31-44.

48. O'Leary K, Carroll C. The online poker sub-culture: dialogues, interactions and networks. J Gambl Stud. 2013;29:613-30.

49. Dagaev D, Stoyan E. Parimutuel betting on the eSports duels: evidence of the reverse favourite-longshot bias. J Econ Psychol. 2020;81:102305.

50. Williams LV, Reade JJ. Prediction markets, social media and information efficiency. Kyklos. 2016;69(3):518-56.

51.• Brown A, Rambaccussing D, Reade JJ, Rossi G. Forecasting with social media: evidence from tweets on soccer matches. Econ Inq. 2018;56(3):1748-63 Sentiment from Tweets can be used to predict soccer matches, and has particular value after certain events.

52. Hong Y, Skiena S, editors. The wisdom of bookies? sentiment analysis vs. the NFL point spread; 2010: Citeseer.

53.• Schumaker RP, Labedz CS, Jarmoszko AT, Brown LL. Prediction from regional angst - a study of NFL sentiment in Twitter using technical stock market charting. Decis Support Syst. 2017;98:80-8 Models relative sentiment to predict outcomes in NFL matches.

54. Peeters T. Testing the wisdom of crowds in the field: Transfermarkt valuations and international soccer results. Int $J$ Forecast. 2018:34(1):17-29 Uses data from an online community to predict soccer match outcomes.

55. Brown A, Reade JJ. The wisdom of amateur crowds: Evidence from an online community of sports tipsters. Eur J Oper Res. 2019;272(3):1073-81 Finds online tipsters have informational value above betting odds.

56. Feddersen A, Humphreys BR, Soebbing BP. Casual bettors and sentiment bias in NBA and NFL betting. Appl Econ. 2020;52(53):5797-806 Identifies sentiment bias towards popular teams in NFL but not NBA.

57. Feddersen A, Humphreys BR, Soebbing BP. Sentiment bias and asset prices: evidence from sports betting markets and social media. Econ Inq. 2017;55(2):1119-29.

58. Schumaker RP, Jarmoszko AT, Labedz CS. Predicting wins and spread in the Premier League using a sentiment analysis of twitter. Decis Support Syst. 2016;88:76-84.

59. Godin F, Zuallaert J, Vandersmissen B, De Neve W, Van de Walle $\mathrm{R}$, editors. Beating the bookmakers: leveraging statistics and Twitter microposts for predicting soccer results. KDD Workshop on Large-Scale Sports Analytics; 2-14.

60. Barberis N, Thaler R. A survey of behavioral finance. Handb Econ Financ. 2003;1:1053-128.

Publisher's Note Springer Nature remains neutral with regard to jurisdictional claims in published maps and institutional affiliations. 